\title{
The activities of the Government Population Council aimed at limiting health care inequalities
}

\author{
Janusz Szymborski', Witold Zatoński ${ }^{2,3}$ \\ 'The Government Population Council, Warsaw, Poland \\ ${ }^{2}$ Health Promotion Foundation, Nadarzyn, Poland \\ ${ }^{3}$ Higher Vocational State School in Kalisz, Poland
}

ADDRESS FOR CORRESPONDENCE: Prof. Janusz Szymborski, The Government Population Council, 208 Aleja Niepodległości, 00-925 Warsaw, Poland, e-mail: janusz.szymborski@gmail.com

Dedicated to the memory of Prof. Zbigniew Strzelecki, Chairman of the Government Population Council in the years 1999-2016

\section{INTRODUCTION}

Demographic changes, including the aging of populations, tend to increase the frequency of and also change the structure of diseases, significantly increase the cost of treatments and place the balance of health care systems at risk. Changes in environmental conditions, including those related to widening social inequalities, increase the risk of large-scale catastrophes, epidemics and social pathologies. Faced with these challenges, the European Union adopted three strategic objectives for the years 2008-2013: to improve the health of Europe's aging populations by promoting health and preventing illness; to protect citizens from health threats; and to support the development of dynamic health systems and new technologies ${ }^{1}$.

In 2014 the European Parliament and the EU Council set up a Third Programme for the Union's Action in the field of health for the period 2014-2020². This is an integral element of the programme "Europe 2020: A strategy for smart, sustainable and inclusive growth". The overall objectives of this programme are: to improve the health of EU citizens and reduce health care inequalities by promoting health, encouraging health-related innovation, enhancing the stability of health care systems and protecting EU citizens from serious cross-border health

Decision No. 1350/2007/EC of the European Parliament and EU Council dated October 23rd 2007, establishing a second community action programme with regard to public health for the years 2008-2013, OJ No. L 301 dated November 20th 2007.

${ }^{2}$ Regulation of the European Parliament and Council (EU) No. 282/2014 dated March 11th 2014 on the establishment of a 3rd EU Health Action Programme (for the years 2014-2020) and repealing Decision No. 1350/2007/EC. threats. Fulfilling these goals at the national level requires broad multi-sector, interdisciplinary involvement by state and local authorities, public institutions and society.

The Government Population Council (the GPC) is the Prime Minister's advisory body on issues related to demographics and population policy. Since its establishment in 1974, one of the GPC's key areas of interest has been public health, within the framework of which the GPC initiates legislative work, reviews legislation, monitors the health of the general public and selected populations, participates in analytical and programme work, organizes or participates in the organization of scientific conferences, publishes reports, its official positions and expert opinions on issues, and represents Poland's position at international conferences. From 1999 until his death on January $6^{\text {th }} 2016$, the chairman of the Government Population Council was Professor Zbigniew Strzelecki (Doctor of Economic Sciences) of the Warsaw School of Economics (born August 25 $5^{\text {th }}$ 1949), founder member and president of the Polish Demographics Society, and head of the Local Government and Local Economy Faculty at the Warsaw School of Economics. The present work is dedicated to Professor Strzelecki's memory for his enormous contribution to the development of public health in Poland and to reducing inequalities in the health of Polish society. This paper focuses on discussing the achievements of two demographics congresses organized by the GPC at the initiative of Professor Strzelecki, and that Council's activities in the field of public health as expressed in the 
course of plenary sessions during scientific conferences, in annual reports on the country's demographic situation, and the positions held by the GPC. Particular attention has been paid to the $1^{\text {st }}$ Demographics Congress, the preparation of which became the responsibility of Professor Strzelecki immediately upon his taking up the position of GPC Chairman, and whose findings set the course of the Council's work for the years ahead, constituting the cornerstone of important analytical and programme research and bringing about spectacular results also in relation to many important public health issues.

\section{THE 2001/2002 $1^{\text {ST }}$ DEMOGRAPHICS CONGRESS AND POLAND'S POPULATION POLICY OBJECTIVES FOR 2004}

The Government Population Council entered the $21^{\text {st }}$ century by organising the $1^{\text {st }}$ Demographics Congress in Poland (September 2001 - November 2002). The message put out by this Congress was an appeal to Polish society on such fundamental issues as the continuity of generations, and thus also our nation's and state's place in the modern world. In the inaugural debate, the participants emphasised that one of the most important conditions for proper development of demographic processes is an improvement in the health of society based on the promotion of health, pro-health education, and the outlining and popularisation of a lifestyle conducive to health, including a sense of responsibility for one's own health. Among the five papers to open this congressional debate was a speech by Professor Witold A. Zatoński concerning development of the health situation in Poland and other countries of Central and Eastern Europe. Analysing the rapidly changing conditions in the first decade of Poland's systemic transformation with regard to mortality rates due to cardiovascular diseases, the author drew particular attention to the connection between these favourable health trends and changes in diet in all age groups and all regions of Poland. This observation mainly concerned the increasing consumption of vegetable oils and the reduced consumption of animal fats [1].

This debate, conducted over more than a year, led to a more thorough diagnosis and the development of recommendations for action in important public health areas. On November $25^{\text {th }} 2002$, during the closing session summarizing the achievements of the Congress, Professor Zbigniew Religa, in a speech entitled "Health, mortality and population policy. Poland - Europe" and presented in the presence of the highest state authorities, linked the significant decrease in mortality rates due to cardiovascular diseases in Poland with favourable changes in diet and a reduction in the number of cigarettes smokers. At the same time he drew attention to the unusually dynamic, unprecedented developments in cardiology and cardiac surgery, made possible by the National Heart Protection Programme, implemented since 1993, and called for this programme, halted in 2002, to be reac- tivated [2]. Substantive arguments for the implementation of health programmes that bring about scientifically proven effects and include tasks aimed at primary prevention (risk factor elimination), secondary prevention (early detection of risk factors and diseases) and modern treatments were developed in the presentations made by Professors W. Zatoński and Z. Religa during a panel session devoted to health. The Declaration of the $1^{\text {st }}$ Demographics Congress also recognised that, from the point of view of Poland's demographic history, of particular importance was implementation of a coordinated public health policy based on the provisions of the National Health Programme. Four out of the 21 volumes of congressional publications directly concerned public health issues: - Vol. III. School medicine. Chief problems and the directions for systemic solutions (2002), ed. J. Szymborski, the Government Population Council, RCSS (Regional Centre for Strategic Studies), Warsaw; Vol. IX. Cardiology and Oncology in Poland at the beginning of the $21^{\text {st }}$ century. Their current state, challenges and perspectives (2002), ed. M. Nowacki, Z. Religa, W. Zatoński, the Government Population Council, RCSS, Warsaw; Vol. XI. Poland's place in Europe in the solving of prevention problems, detection of early forms and treatment of gynaecological cancer (2002), ed. J. Zieliński, the Government Population Council, RCSS, Warsaw; Vol. XVI. Reproductive health in Poland - current state and development prospects (2003), ed. K. Niemiec and B. Balińska. In eight other volumes, content relating to public health formed an important part of the publications.

The practical and direct effect of these congressional debates has been the reactivation of the National Heart Protection Programme and work on the preparation of a National Programme for the Control of Cancer, as well as discussion on the development of a new version of the National Health Programme.

The outcome of the congressional debates was the work undertaken in 2002-2004, coordinated by Professor Z. Strzelecki, on preparing the objectives of a population policy programme in Poland, with the Government Population Council defining population policy as the "calculated, long-term impact of the state and other public and non-public entities on the course of the population's natural and migratory movement processes serving to shape the desired state and structure of the population by creating social, economic and political conditions conducive to demographic processes that ensure the biological survival of the nation and sustainable socio-economic development". In the proposed definition of population policy, health protection policy was recognized as commensurate with other social policy areas, such as family, housing, education, social security and employment. In 2004, the GPC adopted population policy guidelines for Poland developed by a team of experts, and these were subjected to extensive public consultation and in 2006 forwarded to the Council of Ministers [3]. Of the four 
general objectives, public health was the direct concern of objective 3 - "Improvement in the health of the population and a reduction in mortality", but specific tasks closely related to health protection were also included in general objective 1 - "Improvement of the conditions for the emergence and functioning of families and those encouraging childbirth and an increase in birth rates" and in general objective 2 - "The creation of conditions conducive to integration in the aging society". Certain links to public health can also be found in the fourth general objective concerning migration.

\section{PRIORITY 1: IMPROVING THE HEALTH OF NURSING MOTHERS AND INFANTS}

A healthy start to life and the harmonious development of new generations are the key objectives of the World Health Organization's Health 21 policy, and have particular legislative foundations in the Constitution of the Republic of Poland, the Convention on the Rights of Children and the documents of the UN World Summit on Children. Examining the issues of health care for nursing mothers and infants in the context of the population policy in the Objectives, three operational goals were focused on, with a number of specific tasks being assigned to them.

1. To improve the quality of procreation by among other things taking coordinated action to: promote healthy lifestyles and counteract attitudes and behaviours among women of childbearing age deleterious to their health; improve accessibility to and quality of preventive and curative care for women during childbirth and confinement; ensure comprehensive medical care for babies born underweight and prematurely, using a proven threestep reference system; restore the supervision and monitoring system for newborns developed in the years 2000 2001, and implement the latest developments in medical science and technology, including telematics; and ensure a system of adequate social welfare and family benefits, in particular for socio-economically disadvantaged communities and those affected by social ills.

2. To reduce morbidity and mortality among children and adolescents by coordinated action at all levels of public health policy, in particular the elimination of disabling and causative factors leading to developmental defects, chronic diseases and disabilities, including environmental factors and those resulting from children's role as consumers; full implementation of universal preventive testing in basic health care centres and in educational institutions, with paediatricians playing a key role; maintaining the progress achieved in haematology and paediatric cardiology by providing adequate funding for benefits; development of early diagnosis of such problems as developmental defects, genetically determined diseases, and metabolic, allergic and neurological diseases; adequate health care and social assistance for children and families suffering from developmental disabilities, chronic illnesses and disabilities, including mental retardation, especially for communities affected by socio-economic problems and social ills; development and implementation of a National Programme for the Prevention and Reduction of the Effects of Health-related Accidents in Children and Adolescents, including problems of violence in families, local communities and schools; restitution and development of a nationwide integrated system of organization, monitoring and supervision in childcare.

3. The restoration of a school-based medical care system involving a series of activities, including: legislative work leading to the adoption of an Act on medical care in schools, using the Act on medical care in the workplace as a model; the organizing of a health education system for all school age children to promote healthy attitudes, behaviours, skills and motivation, and to prevent behaviours detrimental to health; the promotion of a system for providing school meals; improvements to the technical and sanitary conditions in schools; the development of a network of schools promoting health; promoting the introduction of preventive vaccinations in schools; the implementation of a system for early detection of risks, deviations in health and psychological and somatic development, including screening for health balances, and dental prophylaxis in schools and primary care centres; providing access to adequate specialist care, including rehabilitation and correction, as well as dental care; the implementation of a medical case system for the needs of pupils and schools, including assessments of maturity to attend school, qualifications for physical education and sports and vocational guidance; the development of a system of pre-graduate and post-graduate education for teachers, psychologists, doctors and nurses in the field of health education, health promotion and early detection of health problems among pupils; the creation of an integrated, three-tier system of organization, supervision and monitoring in school-based medical care; the restoration of a medical specialization focused on school-based medical care; and the funding of a school-based medical care system based on local government budgets (providing conditions for ensuring medical care in schools, local districts and provinces, and health promotion), the health fund (health services, prevention programmes, and health promotion programmes), and the state budget (health policy programmes, specialist supervision, methodological and organizational supervision, sanitation inspections, education, and scientific research).

\section{PRIORITY 2: REDUCING MORBIDITY AND MORTALITY RATES DUE TO CARDIOVASCULAR DISEASES}

The basic premise for action needing to be taken in the field of cardiology has been, on the one hand, the unsatisfactory morbidity and mortality rates in Poland compared to western European countries, and on the other hand, the positive effects of the National Heart Programme developed by the cardiologists of the Polish 
Cardiac Society and approved in 1993 by the Ministry of Health and Social Welfare and the Polish Parliament's Health Committee. This programme has led to a broad range of actions being undertaken to promote health and prevent cardiovascular disease among the general public, and has also achieved significant improvements in the availability and effectiveness of diagnostic, therapeutic and rehabilitation services for patients suffering from cardiovascular diseases. The Objectives include a recommendation that the National Heart Programme be continued as a key condition for achieving the strategic goal of reducing rates of morbidity and mortality due to cardiovascular disease and achieving rates comparable with those in other countries of the European Union. It has been determined that five operational objectives and a number of specific tasks, as listed below, need to be accomplished in order for the National Heart Programme to achieve its strategic goal.

1. Development of primary prevention of cardiovascular diseases (also known as CHUK - prophylaxis of cardiovascular diseases) in children and adults by: developing and popularising activities to promote healthy behaviour (proper nutrition, appropriate physical culture, harmonious interrelationships); the prevention and combating of behaviour patterns detrimental to health, especially smoking, combating obesity, hypertension and stress; the implementation and provision of systemic programmes enabling screening to be conducted for risk factors, such as cholesterol and glycaemia tests; giving priority to preventive activities in public health policy across all sectors of social and political life, at all levels of governance; emphasizing the right place and role of primary prevention of cardiovascular diseases in the work of medical staff, especially GPs, which must be allocated appropriate funds as well as teaching and organizational support; and recognition that the prerequisite for effective primary prevention of cardiovascular diseases is the restoration and development of an integrated school-based medical care system.

2. Providing universal access to highly specialised cardiac surgical and non-surgical procedures for all those in need through the implementation of a unified, integrated rescue system, including the organization of a 24 -hour haemodynamic duty roster system and intensive development of modern invasive cardiology, electrotherapy and cardiac surgery techniques; the strengthening of existing regional and central cardiac and cardiac surgery centres so that these may develop and implement the latest world achievements in medical technology, diagnostics and the treatment of cardiovascular diseases.

3. The introduction and ensured availability of modern diagnostic and therapeutic methods for the proper treatment of cardiovascular disease patients by: increasing the number of beds available for intensive cardiac treatment and cardiac rehabilitation; the equipping of cardiac centres with ultrasonographs, angiocardiographs and electrotherapy apparatus.
4. Promoting the use and monitoring the efficacy of appropriate cardiac treatment drugs by: providing possibilities for adequate use of cardiac treatment drugs reducing the risk of death, heart failure and stroke (antiplatelet drugs, angiotensin converting enzyme inhibitors, statins, and beta-blockers); monitoring the pharmacotherapy of outpatient wards; conducting proper training courses for medical staff.

5. Optimizing the functioning of the organization and supervision system in health care for cardiovascular patients, at both the national and regional level, with the introduction of a system of accreditation for cardiac care centres developed by the Polish Cardiac Society.

\section{PRIORITY 3: REDUCING MORBIDITY AND MORTALITY RATES DUE TO CANCER}

Increasing rates of cancer-related morbidity and mortality and the significant distance between Poland and Western European countries in this respect have constituted an important basis for prioritizing oncology in the Objectives of our population policy. The strategic goal of the National Programme for Cancer Prevention in Poland, prepared as the result of work by many medical circles, including above all oncologists, is to reduce the growth of cancer-related illnesses and the cancer mortality rate. The experience of many countries also shows that coordinated projects included in national programmes lead to both a gradual reduction in cancer cases and a very high cure rate among such patients. The Objectives contain a catalogue of activities necessary to achieve the goals of the National Programme for Cancer Prevention.

1. Development of health education and health promotion aimed at reducing smoking and developing proper eating habits and reducing carcinogenic exposure in the workplace and the home. These actions, coordinated within the framework of the state's health policy programme, should be appropriately funded to consolidate existing results and bring about further progress in the prevention of cancers among those addicted to nicotine.

2. Forming and popularising the principles of healthy eating, which should contribute to reducing the incidence of gastrointestinal and breast cancers. The achievement of real health and environmental education results is linked to the urgent need to rebuild a school-based medical care system.

3. The popularisation of public screenings conducted by specialized centres, for detection of pre-cancer conditions and cancer in its early stage: cervical cancer (smear tests), breast cancer (mammographs), colon and stomach cancer (endoscopic examinations), and prostate cancer (PSA tests). This requires educational measures aimed at the whole of society, appropriate changes in the education of pre-clinical medical staff, and the creation of a system of permanent training for doctors of various specialties and a system of oncology, cytotechnology and radiology training for nurses. 
4. The popularization of modern methods of early cervical and breast cancer diagnosis - especially in women aged over 50 and women from families at increased risk of illness (mammography, sonomammography, and fine needle aspiration biopsy for BAC - bronchioloalveolar carcinoma), prostate and gastrointestinal tract cancer and skin melanomas.

5. Modernization of specialized cancer treatment resources, including further extension and modernization of the radiotherapy equipment base, so that this method is universally available to all those in need (60-70\% of all those with malignant tumours - at various stages of progression - with simultaneous implementation of standards to ensure the quality of radiotherapy.

6. The implementation of new methods of combined treatment of tumours in several common locations (surgery + chemotherapy + radiotherapy) in a network of specialized oncology hospitals and medical academies. The primary purpose of such a network of oncology hospitals is to provide specialized oncology care for approximately $50 \%$ of all malignant tumour patients who require combination therapy (surgery and/or radiotherapy and/or chemotherapy) and all patients requiring radiotherapy, including where radiotherapy as a separate radical, complementary or palliative treatment is indicated.

7. Implementation of molecular and immunological methods to predict the risk of cancer, an increase in the percentage rate of early diagnosis of malignant tumours, prediction of the response to various healing methods as the basis for the optimization of therapies, and development of more effective treatments for cancer.

8. Popularization of rehabilitation methods following oncology treatment and the implementation of new methods of symptomatic treatment and pain management. Indications for such procedures exist in 30-50\% of patients with advanced cancer and in this respect cooperation with the country's already formed palliative medicine department is necessary.

9. Ensuring conditions for further development, based on the implementation and popularisation of the progress made in knowledge, diagnostics and treatment of leukaemia and lymphocytic tumours in adults and paediatric cancers.

10. Implementation of a system for monitoring the effectiveness of treatments in combating cancer, which requires the development and modernization of the system for registration of cancer patients and deaths due to malignant tumours in Poland, so as to obtain full information about cancer cases, the stages of progression during the treatment period and the 5-year survival of patients in all regions of the country. This involves the need to expand the Oncology Centre's IT system and enter into it data about centres located around the country, in order to obtain reliable information concerning treatment results, and the creation of a treatment quality control system.
11. The provision of state budget funds for combating cancer. The argument for this is the experience of all countries - especially the United States and the Scandinavian countries - which have achieved measurable results in this respect.

12. Organization of supervision over the implementation of a programme and the establishment of a council which, alongside oncologists and specialists in public health and finance, should be composed of people who enjoy the public's confidence.

\section{PRIORITY 4: THE PROMOTION OF HEALTH AS A FACTOR FOR IMPROVING THE HEALTH OF THE POPULATION AND THE ASSOCIATED QUALITY OF LIFE}

Based on documented assessments that the state of health of the Polish public requires intensive measures enabling its improvement and development, the Objectives draw attention to the constantly changing conditions governing health, which are dependent on the changes taking place in the country's political, social and economic life. It is therefore recommended that a whole host of interdisciplinary activities be undertaken.

1. Adoption of an Act concerning a new National Health Programme, with a clear definition of the terms and scope of funding of activities ensuing from implementation of the programme's objectives.

2. Improved performance of local government tasks in the field of public health policy resulting from the so-called local government act, which obliges local governments at all levels to protect and promote health.

3. The establishment of State Health Monitoring, which would serve as a homogeneous source of health information without the need to construct a system for monitoring results and the achievement of operational objectives of each version of the National Health Programme. In the future, State Health Monitoring could be expanded and combined with State Environmental Monitoring, which would naturally combine the monitoring of key factors so closely linked to each other in terms of their impact on human health.

4. The creation of structures dealing with a wide range of health promotion within the framework of the existing (since the end of last year) National Institute of Public Health.

5. Implementing World Health Organization projects and programmes such as Healthy Cities, Healthy Workplaces, Health Promoting Schools, Health Promoting Hospitals, and the CINDI (Countrywide Integrated Noncommunicable Disease Intervention) project, whose activities are aimed at promoting health, mainly through the prevention of non-communicable diseases and the development of health maintaining behaviours. It would be advisable to implement and develop such "native" projects and programmes as the Local Government Centre for Ecology and Health, Healthy Home, and Health Promotion in Primary Health Care. 
6. Organization and coordination of actions to prevent and limit the effects of injuries and accidents. The establishment of a National Centre for Accident Prevention and Combating the Consequences of Accidents should significantly reduce the number of avoidable deaths through the appropriate organization of activities and education, which will also allow for better use of the funds allocated for these purposes.

7. Development of the existing health care and health promotion system, which involves the need to develop and implement activities and methods that enable the use of a health care system and health promotion programmes and the preparation of so-called safe health policy programmes that include developing skills for health diagnosis, and health impact assessment with regard to drawn up and implemented health policy programmes.

\section{THE 2 ${ }^{\text {ND }}$ DEMOGRAPHICS CONGRESS 2012 AND POLAND'S POPULATION POLICY OBJECTIVES FOR 2013-2016}

In January 2011, to update the objectives of the population policy's action programme, the President of the Government Population Council, Professor Z. Strzelecki, appointed a team composed of Council members - representatives of scientific circles and ministries. The team's task was to prepare an updated draft of Poland's Population Policy Objectives, while leaving its four main goals unchanged, for the detailed preparation of which working teams of experts were assigned.

Taking into account the current health situation of the population, the challenges related to the demographic future of Poland and the experience of other countries, the Council's experts on health, following in-depth discussions, decided that achievement of those public health policy goals considered strategic from the point of view of population policy would be possible on condition that six health priorities were given precedence. Three of those priorities - 1) improving the health protection of women and medical care for nursing mothers and infants, 2) reducing morbidity and mortality rates due to cardiovascular diseases, and 3) reducing the morbidity and mortality rates due to cancer - are similar to those in the Population Policy for Poland of 2004. Two further priorities were added for the current version of the Objectives, namely: 4) improvements in the field of mental health, and 5) reduction of morbidity and mortality rates due to chronic non-communicable diseases by improving society's nutrition and its increased physical activity. The final priority was: 6) promotion of health as a strategy for solving modern health problems. Although the latter was included in the previous version of the Objectives, this priority underwent a major revision. The justification for this approach, supported by the results of scientific research and analysis, was included in a paper pub- lished in early $2012[4]^{3}$. The results of this health team's work were included in an updated draft of Poland's population policy objectives, which became the subject of deliberations and evaluation by the Government Population Council and was subsequently submitted at the $2^{\text {nd }}$ Demographics Congress.

The inauguration of the Congress took place on $22^{\text {nd }}$ and $23^{\text {rd }}$ March, 2012. In one of the panel sessions entitled "The state of society's health - its impact on life expectancy and the country's future demographics", participants in the debate focused on two themes. The first was the health of the youngest generation and the health of the population of reproductive age, which is related to the problem of fertility and quality of life. This decrease in natural population growth is a pan-European problem, but the fact that Poland is one of the countries with the lowest fertility rates must give rise to anxiety. For this reason the discussion focused on the importance of health care for pregnant women and infants and the role of investing in the health of the younger generation, as well as the search for the right tools to improve the health of men and women of reproductive age and the combating of premature morbidity and mortality due to chronic diseases (coronary heart disease, stroke, cancer, asthma, diabetes, obesity, and hypertension) and the prevention and combating of infertility. The discussion's second subject concerned preventing disability and the inability of a growing population of older people to care for themselves. It was emphasized that the prolonged life spans and aging of the population, which are in themselves positive and desirable phenomena, increase the need for both basic and specialized medical care, hospital treatment, medicines, medical equipment and facilities, as well as care services, which poses the health and social policy a number of challenges. There is much to be done in this area, especially since the reform efforts of the transition period, focusing on the successful reconstruction of democratic institutions, the construction of a market economy, and establishment of the foundations for self-government and a civil society have only marginally reduced the deficits associated with unequal opportunities for the less educated, the poor of health, and those with low incomes or of advanced age. The goals

\footnotetext{
${ }^{3}$ The Government Population Council's team of experts handling revision of goal 3 III of the Population Policy Objectives: Professor Janusz Szymborski of the Government Population Council, the Public Health Faculty, University of Warsaw - Chairman of the Council's team of experts; Professor Bogdan Chazan, Faculty of Medicine and Health Sciences, the Jan Kochanowski University in Kielce, member of the Government Population Council; Professor Wojciech Drygas, Department of Epidemiology, Prevention of Cardiovascular Diseases and Health Promotion, Warsaw Cardiology Institute; Professor Mirosław Jarosz, Food and Nutrition Institute; Dr. Jacek Moskalewicz, Department of Alcoholism and Toxicology Research, Psychiatry and Neurology Institute; Krzysztof Przewoźniak, Oncology Centre Institute's Department of Epidemiology and Cancer Prevention; Dr. Włodzimierz Sekuła, Food and Nutrition Institute, member of the Government Population Council; Dr. Zofia Słońska, Department of Epidemiology, Prevention of Circulatory Diseases and Health Promotion, Warsaw Cardiology Institute, member of the Government Population Council; Professor Witold Zatoński, Oncology Centre Institute's Department of Epidemiology and Cancer Prevention, member of the Government Population Council
} 
and health measures contained in the Objectives were duly approved in the conclusions of the panel debate and the following was recommended: 1) reorientation of the existing health care system, so that development of modern diagnostic and therapeutic methods is accompanied by recognition of the role of health education, health promotion and risk and disease prevention, which entails the need to build appropriate infrastructure and legislative foundations for effective public health activities, including the adoption of a public health act; 2) strengthening of the role of national health protection programmes as tools for implementing those health priorities seen as important from the point of view of population policy. A detailed discussion on the course of the sessions opening the Congress is included in a publication issued by the Government Population Council [5].

The draft Objectives were in subsequent months the subject of debates during meetings of the Government Population Council and discussions during 15 scientific symposia and conferences, two of which concerned health: "Let's save lives and support parenting" held in Warsaw on March 21 $1^{\text {st }}$ 2012, and "Primary prevention of cancer" on $12^{\text {th }}$ and $13^{\text {th }}$ November, 2012 [6]. The closing sessions of the $2^{\text {nd }}$ Demographics Congress were held on $22^{\text {nd }}$ and $23^{\text {rd }}$ November, 2012. The draft Objectives of Poland's population policy were adopted in the Congress Declaration in which the participants of the $2^{\text {nd }}$ Congress addressed Polish society, public authorities, civic organizations, churches and religious associations, employers, local communities and trade unions with a demand for a coordinated social policy, economic and population-related actions capable of reversing the adverse phenomena in the country's demographic processes, including actions involving the improvement of health and a reduction in mortality rates and conditions conducive to an active, creative and dignified life for the aged.

Following the Congress, work was undertaken on updating the Objectives with the intention of presenting them to the Polish Government as a basis for drawing up the National Population Policy Programme.

Of great importance for deepening and updating the diagnoses and recommendations related to the problem of reducing the morbidity and mortality rates of the Polish population were the Government Population Council's scientific conferences organized on the initiative of Professor Z. Strzelecki, with the participation of outstanding experts in medicine, public health, social policy and demographics. On $3^{\text {rd }}$ December, 2013, a conference on the problems of Polish oncology was held, resulting in the publication and approval by the Government Population Council of a Position on cancer morbidity and mortality rates and the need to improve prevention and the treatment of cancer patients in the face of the demographic challenges faced by Poland [7].

On $1^{\text {st }}$ October, 2014, the Column Hall in the Prime Minister's Chancellery was the venue of a conference entitled "Population changes in Poland, the demographic future" organized to celebrate 40 years of the Government Population Council's operations, during which outstanding experts discussed the socio-economic challenges faced by an aging society, including challenges with regard to the health of society [8].

Publication of the Government Population Council's position on reducing morbidity and mortality rates due to cardiovascular disease in the face of the demographic challenges faced by Poland was the outcome of a scientific conference held on $9^{\text {th }}$ June, 2015, attended by demographers and social politicians, this being debated at a scientific conference entitled "Morbidity and mortality due to cardiovascular disease and Poland's demographic situation" organized by the Government Population Council on $9^{\text {th }}$ June, 2015, at the headquarters of the Central Statistics Office [9].

Taking into account the current assessment of the population's health situation [10-12], the results of the Government Population Council's plenary debates and the wording of the Council's Official Positions, as well as the EU recommendations [12], and the challenges related to Poland's demographic future [12], the current version (2015-2016) of the Objectives, six of the public health priorities adopted by the $2^{\text {nd }}$ Demographics Congress, entitled "Improving public health and reducing mortality rates", were retained in the third chief objective, and an additional priority was included for the prevention and control of infections, infectious diseases and cross-border threats. The Council's Team of health experts was joined by Dr. Joanna Didkowska from the Department of Epidemiology and Cancer Prevention at the Oncology Centre Institute; Dr. Iwona Paradowska-Stankiewicz from the Department of Epidemiology at the PZH National Institute of Public Health; Dr. Urszula Sulkowska from the Department of Epidemiology and Cancer Prevention at the Oncology Centre Institute; and Professor Jacek Wciórka from the $1^{\text {st }}$ Psychiatric Clinic at the Psychiatry and Neurology Institute. Priority public health issues are interconnected by: the focus on risk factors, which are mostly common; emphasis on prevention of diseases and health hazards at every stage of life; and appreciation of the role of health promotion as a strategy for solving health problems far beyond the realm of remedial medicine.

The proposed public health priorities have important connotations with achievement of the other three chief goals of Poland's population policy. The first chief goal, entitled "Creating conditions conducive to the establishment of families, especially through marriage and the accomplishment of procreation plans", is directly linked to improvement in health care for nursing mothers and infants, whereas the question of reducing the incidence of chronic non-communicable diseases, including cardiovascular diseases and malignant tumours, improving mental health, improvements in nutrition and physical activity and modern health promotion are connected 
with many of the actions directed at optimizing the conditions for the establishment and functioning of families and the prevention of reproductive problems. The second chief goal, entitled "Creating conditions conducive to integration in an aging society - reducing the risk of social exclusion of the elderly, dependent and disabled" is in line with all the approved public health priorities, not excluding the priority aimed at improving health care for nursing mothers and infants (fetal causes of health problems in adult life and old age). Public health experts agree on the need to complement the integration paradigm as it relates to the elderly to include issues related to healthy aging. The fourth chief goal of the Objectives, entitled "Defining the principles and directions of the state's migration policy in the era of European integration", is linked to the public health priority concerning infections and infectious diseases, which is justified by among other things the need for constant vigilance in the prevention of those hazards related to the movement of people in Europe. Within the framework of Poland's migration doctrine, it is also important to formulate questions related to the emigration of qualified medical personnel, including doctors and nurses, and the influx of doctors to Poland from other countries. Each of the seven public health priorities contains detailed data enabling in-depth diagnosis of the issues at hand. On this basis, directional recommendations and implementation tasks have been formulated with an indication of the recipients and sources of funding. Proposals have also been put forward concerning further analytical and research work.

\section{REPORTS BY THE GOVERNMENT POPULATION COUNCIL ON POLAND'S DEMOGRAPHIC SITUATION}

Each of the annually published Government Population Council's reports on Poland's demographic situation contains sections on mortality and life expectancy rates in Poland and other selected countries and the geographical differences between those indicators. On the initiative of Professor Z. Strzelecki, the Report published in 2006 [13] contained an additional, extensive section on selected health problems of the population. This showed, among other things, that the geographical diversity of malignant cancer risk in general has for many years indicated a higher cancer risk in the western and north-western parts of Poland and lower risks in the south-east. This pattern is characteristic in both sexes. In turn, outpatient care for people with mental disorders and behavioural disorders treats more urban than rural dwellers, and more women than men. In both outpatient and 24-hour care cases, large geographical differences have been observed in the frequency of hospitalization and, as in outpatient care, the difference between the highest and lowest rates is almost double. Significant differences in the incidence of particular diseases in different parts of the country constitute a serious epidemiological problem with regard to infectious diseases in Poland.
The Government Population Council's recommendations, developed on the basis of an in-depth diagnosis of the epidemiological situation, signed in the Report by Professor Z. Strzelecki, and addressed to the appropriate ministers (those for Health, Labour and Social Policy, Finance, Justice, Internal Affairs and Administration, and National Education) included the following actions:

- developing and reviewing preventive and curative programmes in the field of cardiology and cardiac surgery based on an assessment of the epidemiological situation, taking into account both national and regional differences;

- full implementation of the 2005 Act concerning a "National Programme for the Prevention of Cancer"; in addition, it was recommended that a ban be introduced on smoking in public places and the price of cigarettes be raised, which would be effective in preventing the spread of tobacco smoking and, consequently, the development of many cancers (including lung cancer) as well as other chronic diseases, e.g. cardiovascular disease; the passing of a medical records act, which will allow the collection of data concerning malignant tumours and the conducting of certain analyses, e.g. the calculation of survival rates, making it possible to assess the effectiveness of treatment and compare the results of treatment between medical institutions;

- developing information and communicating knowledge to young people on the subject of procreation, the link between irresponsible and reckless endangering of health and subsequent failure to reproduce, shaping sensible attitudes towards life, responsible and conscious parenthood, and preparation and upbringing of children in the family;

- including in health policy the impact on the young generation of behavioural changes, lifestyles, and the publication of reliable knowledge about how to recognize infertility and how to reduce it; facilitating access for adults to modern and effective methods for diagnosis and treatment of infertility, unification of standards of conduct, the organization of medical centres dealing comprehensively and responsibly with this problem;

- disseminating knowledge in society about prevention and early detection of cervical, ovarian and breast cancer;

- preparation and popularisation of pre-natal care; continuation of health programmes aimed at improving medical care during pregnancy and childbirth, including a prevention programme for neural tube defects and premature births; ensuring employment stability for pregnant and post-natal women and the possibility for pregnant and post-natal women to be employed parttime; prolongation of maternity leave; an increased amount of maternity allowance; popularization of free birthing schools; financial support for the "Paediatric Hospital" initiative promoting breastfeeding;

- undertaking actions aimed at providing postmenopausal women with comprehensive preventive, cura- 
tive and rehabilitative medical care and the inclusion of these procedures in the services provided by the National Health Fund; the health needs of these women concern a variety of medical disciplines (including internal medicine, psychiatry, urology, and family medicine); the coordination of medical services should be the responsibility of gynaecologists; the provision of counselling and social and legal assistance for post-menopausal women;

- disseminating knowledge about the dangers to reproductive health related to infections and prevention of the same (lifestyle, monogamous relationships, protective vaccinations, screening for women before and during pregnancy); education and counselling about responsible sexual behaviour; ensuring the availability of methods for the prevention, diagnosis and treatment of sexually transmitted diseases, including HIV infections;

- increased strict enforcement of traffic regulations with regard to road users - particularly the punishment of drunken drivers should be stricter; the introduction of a requirement for pedestrians and cyclists, as well as horse-drawn vehicles on the roads after dusk and at night to use reflective elements;

- enabling children and youth to achieve their full potential for health and development, and to reduce morbidity and mortality rates due to causes that are preventable; in this regard, public health authorities at all levels, sincerely committed to investing in the health and development of children and young people, should adopt a comprehensive strategy for the health and development of children and youth either as an independent programme or as part of another strategy, e.g. national health or a national programme for children, making improvement in the health of children and adolescents an integral part of its activities and assessment of health sector establishments; the introduction of an "equality audit" to ensure that in programming and implementing a health policy, the health sector does not neglect the needs of children and young people from socially disadvantaged backgrounds, for example ensuring that such children have access to proper care.

On the initiative of Professor Z. Strzelecki, one of the Government Population Council's plenary sessions in 2008 was devoted to health safety issues. With the participation of experts from various fields of medicine, the Council adopted a document in which it pointed out that expenditure on health care in Poland, both per capita and as a percentage of GDP, is one of the lowest in the European Union [14]. The Council stressed that in terms of health security, the essence of the EU's strategy is equality of citizens with regard to access to health care, so that in the event of a health risk anyone, regardless of age, gender, place of residence and level of wealth, could benefit from adequate health care. Referring in this con- text to the health security of the Polish population, the Council drew attention to the worrying phenomenon of very large disparities in the average life expectancy and mortality rates between the various regions of the country, some cities and even between the districts of large cities, and to the fact of Poland lagging behind other European Union countries in terms of average health indicators. Based on an in-depth analysis of the current situation and the proportional balance between the public burden, the burden on the state, and the individual burden with regard to health, the Government Population Council postulated that systemic changes in health protection would be required in order to increase patients' possibilities of gaining access to health care services, eliminate limitations to access to services, improve the quality of medical services, make true assessments of the health care provided, increase admissions to medical studies (doctors and nurses), and combine these activities with a reorientation of medical care and recognition of the role of public health in the health care system.

The most recent Report [15] edited by Professor Z. Strzelecki included recommendations relevant to public health and the combating of health inequalities, including those concerning geographical variations in infant mortality and overall mortality rates. Although one of the most spectacular achievements of the last quarter century (1990-2014) is a significant decrease in infant mortality, with the infant mortality rate for 1,000 live births decreasing by more than $77 \%$ over this period (in 1990, 10,600 infant deaths - 19.3\%o, and in 2014, 1583 infant deaths $-4.2 \%$ ), the infant mortality rate in Poland is still twice as high as in those countries leading in this respect. The Government Population Council therefore reiterated its demand for in-depth analyses of the causes of infant mortality and the effectiveness of the systemic preventive and curative measures taken in this respect. This should be achieved by means of a detailed analysis of the factors causing the significant difference in infant mortality rates between provinces and the local districts in those provinces, where the average infant mortality rate for 2002-2012 was at a high level. In order to reduce the phenomenon of "randomness" in the mortality rates when comparing them on an annual basis, the Council is analysing the average annual death rate of infants by province for longer periods. In 2014, the provinces with the highest infant mortality rates were: Zachodniopomorskie (5.3\%) and Podkarpackie (5.0\%), these figures being significantly different from those for provinces with the lowest rates: Świętokrzyskie (3.1\%) and Małopolskie (3.2\%). Between 2002 and 2014, the most favourable situation (4.9-5.4 infant deaths per 1000 births) occurred in the following provinces: Mazowieckie, Opolskie, Małopolskie, Warmińsko-Mazurskie, Świętokrzyskie, Łódzkie, Podlaskie and Pomorskie. On average over this same period, the worst rates in this respect (5.9 to 6.8 infant deaths per 1000 births) were predominantly in the western and 
south-western provinces (Dolnośląskie, Śląskie, Zachodniopomorskie, Lubuskie, Kujawsko-Pomorskie) and the south-east (Podkarpackie and Lubelskie). Also pointed out were districts for which the average annual death rate of infants per 1000 live births during that period was particularly disturbing.

This report also noted a systematic decline in death rates and a prolonged average life expectancy among Polish men and women, which is a consequence of the persistent decline in mortality due to cardiovascular disease and external causes, as well as some cancers. Poland continues to experience higher mortality rates in rural areas compared to cities - in 2014, the rural mortality rate exceeded that for cities by $7 \%$, which is primarily due to the stronger impact of cardiovascular disease, the most common cause of death. In the years 2009-2013, the death rate from these diseases accounted for almost half of all deaths in rural areas, while in urban areas this percentage was more than 4 points lower. The smaller cities also experienced a percentage of deaths caused by external causes. A commonly observed phenomenon was the greater number of reported deaths among men than women. In Poland, the gap between the sexes in this respect not only fails to decrease but has increased over the past two decades - in 1990 the death rate among men, as measured by a standardized coefficient, was $80 \%$ higher than among women, whereas in 2014 their death rate exceeded that for women by $88 \%$. Analysis of the data presented in the Report shows that in most cases the situation in Poland in terms of mortality due to the main causes of death - cardiovascular diseases, cancer and external causes - is worse than in the countries used for comparison. It should be noted, however, that the above-mentioned causes are particularly unfavourable for Poland compared to those countries in terms of those aged 0-64. The standardized death rates for women and men aged 0-64 in Poland exceed those figures in other countries to a much greater extent than those rates set for their whole populations. This is particularly evident in the case of deaths caused by cardiovascular diseases. Taking the above into account, the Government Population Council presented the following recommendations to the Minister of Health: the conducting of in-depth analyses of the causes behind the mortality rate among rural residents being greater than that for cities, especially in terms of availability and quality of preventive and curative care; secondly, an analysis of the reasons for the significant variation in the standardized general mortality rate between provinces. In 2014, with an average mortality rate for Poland of 978.24 , lower mortality rates were recorded in the following provinces: Podkarpackie 898.40; Małopolskie 902.73; Podlaskie 923.55; Pomorskie 949.59; Mazowieckie 951.39; Opolskie 954.25; Lubelskie 978.24. Poland's higher than average mortality rate was however the result of the figures for the following provinces: Zachodniopomorskie 981.79; Świętokrzysk- ie 981.90; Wielkopolskie 982.97; Warmińsko-Mazurskie 994.02; Dolnośląskie 997.50; Kujawsko-Pomorskie 1001.04; Lubuskie 1005.67; Śląskie 1029.99; Łódzkie 1078.92

It should be emphasized that the Government Population Council's reports and official positions are widely disseminated and form the basis for, among other things, assessing the health condition of society, conducting epidemiological analyses and developing prevention programmes. They also provide the basis for the research community to conduct its own tests and analyses.

Professor Z. Strzelecki included the Government Population Council in the consultation process concerning the draft of the Public Health Act and submitted the Council's opinions and comments concerning the Act to the Minister of Health. Although not all those remarks were taken into account, a positive step was the Polish Parliament's adoption of the Public Health Act on September 2015 in a form that could be approved under current conditions and it then being passed by Parliament after nearly 20 years of legislative powerlessness in this respect. The author has expressed his hope that this law will become a solid basis for building Poland's future public health infrastructure and has recommended that the Minister of Health appoint a Plenipotentiary for Public Health, a statutory and publicly authorized body that will be a key institution for the success of the whole project, one whose tasks will be clearly defined, including involvement in the construction and implementation of the Act's main instrument, namely the National Health Programme.

Since a reliable, systematic assessment of the health situation among the country's population, and professional evaluation of the programme activities undertaken, should be the basis for functioning of the public health system in Poland, Professor Z. Strzelecki also submitted to the Minister of Health, within the framework of the Council's consultation regarding the draft public health law, the Government Population Council's position on health care statistics and reporting.

In their conclusions to this paper, the authors wish to emphasize the great contribution of the Government Population Council, during the years its work was headed by Professor Z. Strzelecki, in the development of public health in Poland and in ensuring this area of social policy an appropriate place in the state's overall population policy, including measures in many sectors enabling improvement of the health conditions for the establishment and functioning of families and raising the level of births (increased fertility), general improvements in health and limiting mortality rates among the population's children and adolescents, and men and women of reproductive age, as well as improvements in the health of the older generation.

\section{DISCLOSURE}

Authors report no conflict of interest. 


\section{References}

1. Zatoński W. Kształtowanie się sytuacji zdrowotnej ludności Polski - uwarunkowania, zagrożenia i problemy [Shaping of the health situation of the Polish population - conditions, threats and problems]. In: Polska a Europa. Procesy demograficzne u progu XXI wieku. I Kongres Demograficzny w Polsce. Sesja Końcowa, Tom XVII [Poland and Europe. Demographic processes on the threshold of the $21^{\text {st }}$ century. The $1^{\text {st }}$ Demographics Congress in Poland. Final Session, Volume XVII]. Strzelecki Z (ed.). Rządowa Rada Ludnościowa, RCSS, Warsaw 2003.

2. Strzelecki Z (ed.). Problemy demograficzne Polski przed wejściem do Unii Europejskiej [Poland's demographic problems prior to accession to the European Union]. Polskie Wydawnictwo Ekonomiczne, Warsaw 2003.

3. Założenia polityki ludnościowej w Polsce [Objectives of Poland's population policy]. In: Sytuacja demograficzna Polski - Raport 2004 [Poland's demographic situation - 2004 Report]. Rządowa Rada Ludnościowa, Warsaw 2006.

4. Zdrowie publiczne i polityka ludnościowa, II Kongres Demograficzny, Tom 2 [Public Health and Population Policy, the 2nd Demographics Congress, Vol. 2]. Rządowa Rada Ludnościowa, Warsaw 2012.

5. Strzelecki Z, Potrykowska A (eds.). Polska w Europie. Przyszłość demograficzna. Sesja Inauguracyjna, tom I [Poland in Europe. The demographic future. Inaugural session. Vol. I]. Rządowa Rada Ludnościowa, Warsaw 2012.

6. Szymborski J, Zatoński W (eds.). Prewencja pierwotna nowotworów: ograniczenie ekspozycji na dym tytoniowy [Primary prevention of cancers: limitation of exposure to tobacco smoke]. Zdrowie Publiczne. Monografie, Tom I [Public Health. Papers, Vol. I]. Wszechnica Polska, Warsaw 2012.

7. Potrykowska A, Strzelecki Z, Szymborski J, Witkowski J (eds.). Zachorowalność i umieralność na nowotwory a sytuacja demograficzna Polski [Cancer morbidity and mortality rates and the demographic situation in Poland]. Rządowa Rada Ludnościowa, Warsaw 2014.

8. Strzelecki Z, Kowalczyk E (eds.). Przemiany ludnościowe w Polsce. Przyszłość demograficzna [Population changes in Poland. The demographic future]. Rządowa Rada Ludnościowa, Warsaw 2014.

9. Strzelecki Z, Szymborski J (eds.). Zachorowalność i umieralność na choroby układu krążenia a sytuacja demograficzna Polski [Morbidity and mortality rates for cardiovascular diseases and Poland's demographic situation]. Rządowa Rada Ludnościowa, Warsaw 2015.

10. Zdrowie i ochrona zdrowia w 2014 roku [Health and health care in 2014]. Główny Urząd Statystyczny, Warszawa 2015.

11. Mazur J (ed.). Zdrowie i zachowania zdrowotne młodzieży szkolnej w Polsce na tle wybranych uwarunkowań socjodemograficznych. Wyniki badań HBSC 2014 [Health and health behaviors of schoolchildren in Poland seen against selected sociodemographic conditions. Results of HBSC 2014]. Instytut Matki i Dziecka, Warszawa 2015.

12. Wojtyniak B, Goryński P (eds.). Sytuacja zdrowotna ludności Polski i jej uwarunkowania [The Polish public's health situation and its conditions]. Narodowy Instytut Zdrowia Publicznego Państwowy Zakład Higieny, Warsaw 2016.

13. Sytuacja demograficzna Polski. Raport 2005-2006 [Poland's demographic situation. The 2005-2006 Report]. Rządowa Rada Ludnościowa, Warsaw 2006.

14. Stanowisko Rządowej Rady Ludnościowej w sprawie „Bezpieczeństwo zdrowotne ludności Polski” [The Government Population Council's position on the "Health security of the Polish population”]. Rządowa Rada Ludnościowa, Warsaw 2008.

15. Sytuacja demograficzna Polski. Raport 2014-2015 [Poland's demographic situation. The 2014-2015 Report]. Rządowa Rada Ludnościowa, Warsaw 2015.

\section{AUTHORS' CONTRIBUTIONS}

JS, WZ collected and analysed data, prepared the research concept of the publications, wrote the article. WZ finally approved it. 